\title{
Mother-to-child transmission of HIV in the Southern Region of Santa Catarina, from 2005 to 2015: analysis of risk factors to seroconversion in newborns
}

\author{
Karen Waleska Kniphoff de Oliveira 1 \\ Suzana Kniphoff de Oliveira 2 \\ Ana Beatriz Sanches Barranco 3 \\ Tamara Hoffmann 4 \\ Camila Soares Duarte 5 \\ Rayane Felippe Nazário 6 \\ Chaiana Esmeraldino Mendes Marcon 7 \\ Fabiana Schuelter-Trevisol 8
}

1-6 Universidade do Sul de Santa Catarina. Tubarão, SC, Brasil

7,8 Programa de Pós-Graduação em Ciências da Saúde. Universidade do Sul de Santa Catarina. Av. José Acácio Moreira, 787. Tubarão, SC, Brasil. CEP: 88.704-900.

E-mail: fastrevisol@gmail.com

\begin{abstract}
Objectives: to analyze both frequency and risk factors for seroconversion among newborns of HIV-positive mothers to HIV.

Methods: a cohort study was conducted with children residing in Southern Region of Santa Catarina. Secondary data from the notification files and medical records of newborn's mothers of infected infants were used. The participants were all the newborns from 2005 to 2015 that were exposed to HIV through vertical transmission and attended a municipal health care center.

Results: there were 104 cases of infant exposure to HIV. Seroconversion was confirmed in three cases, two of them died of AIDS during the study period. Breastfeeding $(P R=32.7$; $C 195 \%=10.7-99.5 ; p=0.002)$ and non-use of antiretroviral drugs during pregnancy $(P R=18.2 ; C I 95 \%=2.0-163.0 ; p=0.008)$ were risk factors for HIV seroconversion.

Conclusions: seroconversion rates among neonates in Southern Region of Santa Catarina were similar to the national average. Seroconversion was associated with non-use of antiretroviral therapy during pregnancy and breastfeeding.

Key words HIV infections, Infectious disease transmission, vertical, Seroconversion
\end{abstract}

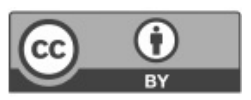




\section{Introduction}

The pandemic of human immunodeficiency virus (HIV) infection represents one of the most serious global health issues. From its emergence in the early 1980 s to 2016 , more than 78 million people have been infected with HIV, and about 39 million have died of acquired immunodeficiency syndrome (AIDS). ${ }^{1}$ According to estimates by UNAIDS, about 37 million people were living with HIV globally at the end of 2016, 2.1 million of whom were children. 1,2

According to the United Nations, $49 \%$ of the pregnant women infected by HIV worldwide received antiretroviral therapy (ARV) in 2010. In 2014 , ARV coverage was as high as $73 \%$ of the 1,070,000 pregnant women.1,2 In Cuba, ARV coverage among pregnant women reached $98 \%$ in 2014, being considered by the World Health Organization, at that time, the first country in the world free of vertical transmission, having only one to two new cases of HIV infection in children under five years of age, annually. 1,3

In Brazil, 92,210 HIV-infected pregnant women were notified from 2000 to June 2015, most of whom living in the Southeast (40.5\%) and Southern (30.8\%) Regions. The rate of HIV detection in pregnant women has been increasing in Brazil, particularly within the $2005-2015$ period. ${ }^{4}$ In 2005 , infant mortality rates were 2.0 cases per 1,000 live births, which increased to 2.6 cases per 1,000 live births in 2014 , representing a $30 \%$ increase. 4 In 2014 , five Brazilian states had HIV detection rates in pregnant women higher than the national average, as follows: Rio Grande do Sul (8.8 cases per 1,000 live births), Santa Catarina (5.8 per 1,000 live births), Rio de Janeiro (4.0 per 1,000 live births), Amazonas (3.8 per 1,000 live births), and Pará (2.7 per 1,000 live births). An increase in rates was also observed among the regions of the country, except for the Southeast, which presented the same rate of 2.3 cases per 1,000 live births in 2005 and 2014. In 2014, the Southern Region had the highest detection rate of all regions, approximately 2.1 times higher than the rate in Brazil. 5

The AIDS detection rate among children under five years of age has been used as an indicator to monitor HIV vertical transmission. In Brazil, there was a reduction of $42.7 \%$ in the detection rate between 2005 and 2015. In the Southern Region, the detection rate decreased by $63.4 \%$ from 2006 to 2015. According to the Ministry of Health, 5 the detection rate of AIDS in children under five years in Brazil was 2.5 per 100 thousand people in 2015 .
These results can be explained by the stork network strategy (Rede Cegonha na Atenção Básica in Portuguese), a primary care system for pregnant women and their children, adopted by all Brazilian states. ${ }^{4-7}$

Although vertical transmission is determined by the number of AIDS cases among children under 5 years of age, few studies have examined seroconversion in neonates to verify the risk factors for HIV infection and what strategies should be implemented to prevent mother-to-child transmission. The aim of this study was to investigate the frequency of seroconversion and analyze its risk factors among newborns of HIV-positive mothers between 2005 and 2015 in the Southern Region Santa Catarina, Brazil.

\section{Methods}

An epidemiological, historical cohort study was conducted in a specialized health care service (CAES, Portuguese acronym), a public health care service in Tubarão, state of Santa Catarina, Brazil, that encompasses an HIV/AIDS referral center for 18 municipalities that form the Association of Municipalities of the Laguna Region (AMUREL, Portuguese acronym), namely: Armazém, Braço do Norte, Capivari de Baixo, Grão-Pará, Gravatal, Imaruí, Imbituba, Jaguaruna, Laguna, PedrasGrandes, Pescaria Brava, Rio Fortuna, Sangão, Santa Rosa de Lima, São Ludgero, São Martinho, Treze de Maio and Tubarão. These municipalities had a total population estimated at 353,989 residents in July 2014.8 It should be noted, however, that not all HIV-exposed children are monitored in this health care service, since the municipalities of Capivari de Baixo, Laguna, and Imbituba also have specialized care centers for HIV/AIDS and other infectious diseases.

The CAES is a leading health center for infectious diseases that treat individuals with sexually transmitted infections/AIDS, tuberculosis, and leprosy. All children born to HIV-positive mothers in Tubarão must be monitored, as of the notification, by the municipal service, and active search is made in cases of non-compliance. ${ }^{6}$ The municipality of Tubarão is served by two hospitals with obstetric center and neonatology service, being a reference in the region. As a result, a large number of births occur in the AMUREL region.

The study included all infants aged $0-18$ months, both boys and girls, who had vertical HIV exposure, born in the study period, attended at CAES, in the AMUREL region, between 2005 and 2015. All chil- 
dren born to seropositive mothers were notified and followed up for seroconversion investigation. Parturients who had no prenatal care or those who underwent HIV testing during pregnancy underwent a rapid HIV testing upon admission for delivery. HIV-infected pregnant women were notified by the maternity health services. Data for this study were extracted from the compulsory notification reports of children exposed to HIV by vertical transmission filed at the CAES in Tubarão. The information was entered into an electronic database for further analysis.

The case definition in this study was based on the seroconversion confirmation during the infant follow-up period (up to 18 months of age). The following maternal variables were examined: age (in years) presented as mean, standard deviation and age group; ethnicity/skin color (white and non-white); education ( $0-8$ and $>8$ years of schooling); occupation (housekeeper, salaried employee, unemployed, student); residency (Tubarão, other municipalities of the region, other municipalities of Santa Catarina) and area of residence (rural or urban); factors associated with vertical transmission, such as use of ARV during pregnancy (yes or no), type of delivery (vaginal delivery or cesarean section), and breastfeeding or cross-feeding (yes or no). The following variables were also included for the newborns: gender (male or female); ethnicity/skin color (white and non-white); peripartum prophylaxis (if ARV was used during labor); duration of ARV regimen after delivery (in weeks); and outcome (infected, not infected, deceased or lost to follow-up). Infants with HIV-confirmed infection at the end of follow-up by mother-to-child transmission had their maternal data on the last $\mathrm{CD}^{+}{ }^{+} \mathrm{T}$-Lymphocyte count and viral load during pregnancy also included in the analysis. The data not found in the records were shown as ignored.

Statistical analysis was performed using IBM SPSS Statistics ${ }^{\circledR}$ software, version 21 (IBM ${ }^{\circledR}$, Armonk, New York, USA). In the descriptive step, categorical variables were expressed as proportions, and nume-rical variables as mean and standard deviation. In order to verify the association between the variables of interest and the HIV infection outcome, Fisher's exact two-tailed test was used for the categorical variables. The level of significance was set at $5 \%$. The number of live births in the AMUREL municipalities within the study period was used to calculate the rate of seroconversion and infant exposure to HIV. 8,9 The estimated total population in these municipalities was based on the 2014 estimates. ${ }^{8}$

The OpenEpi10 software was used to calculate the relative risk, with a confidence level of $95 \%$.

This study was approved by the Research Ethics Committee of the University of Southern Santa Catarina, (Protocol N ${ }^{\circ}$ 1,137,723), on July 15, 2015, according to recommendations by Resolution 466 of the National Health Council of December 12, 2012.

\section{Results}

The study encompassed 104 HIV-exposed infants. The mean age of the seropositive mothers was 27.5 years ( $\mathrm{SD}=6.4$ years), ranging from 16 to 39 years.

Table 1 presents the characteristics and data regarding the gestational follow-up of the seropositive mothers who were followed up to determine HIV seroconversion of their children.

Table 2 shows the demographic and prophylactic characteristics for vertical HIV infection in newborns of seropositive mothers.

Table 3 presents the description of confirmed cases of seroconversion for HIV infection during the study period.

Breastfeeding $(\mathrm{PR}=32.7$, CI95\% $=10.7-99.5$; $p=0.002)$ and non-use of antiretroviral during pregnancy $(\mathrm{PR}=18.2, \mathrm{CI} 95 \%=2.0-163.0) ; p=0.008)$ were risk factors for the occurrence of seroconversion. The use of antiretroviral drugs during delivery ( $p=0.188)$, type of delivery $(p=0.199)$ and antiretroviral use by the newborn after birth $(p=0.235)$ were not associated with the occurrence of seroconversion for HIV infection (Table 4).

Seroconversion was documented in $4.8 \%$ during the study period, ranging from $6.7 \%$ in 2005 to $20.0 \%$ in 2012 (Table 5). Considering the total number of live births in the AMUREL region during the study period, HIV infection rate in pregnant women was 2.2 per 1,000 live births, whereas HIV infection in newborns was 0.1 per 1,000 live births.

\section{Discussion}

In the period between 2005 and 2015, there were 104 infants exposed to HIV, 5 of whom had confirmed seroconversion associated with breastfeeding and no use of antiretroviral drugs during pregnancy. These data corresponded to a rate of 2.2 infected pregnant women per 1,000 live births, which was similar to the national average $(2.7$ per 1,000$)$, but lower than the average in the state of Santa Catarina (3.2 per 1,000 live births). In Santa Catarina, 2,779 HIVpositive exposures during gestation and delivery were reported among the 861,168 live births between 2005 and 2015. Of these, 84 children were infected with HIV, 7 died of AIDS, and 66 were lost 
Gestation-related features of HIV seropositive pregnant women $(n=104)$, attending the town's health care center. Southern Region of Santa Catarina, 2005-2015.

\begin{tabular}{|c|c|c|}
\hline Maternal characteristics & $\mathbf{N}$ & $\%$ \\
\hline \multicolumn{3}{|l|}{ Age (years) } \\
\hline $16-20$ & 10 & 9.6 \\
\hline $21-25$ & 11 & 10.6 \\
\hline $26-30$ & 12 & 11.5 \\
\hline $31-40$ & 19 & 18.3 \\
\hline No information & 52 & 50.0 \\
\hline \multicolumn{3}{|l|}{ Skin color } \\
\hline White & 75 & 72.1 \\
\hline Non-white & 21 & 20.2 \\
\hline No information & 8 & 7.7 \\
\hline \multicolumn{3}{|l|}{ Education (years of schooling) } \\
\hline $0-8$ & 76 & 73.1 \\
\hline$>8$ & 23 & 22.1 \\
\hline No information & 5 & 4.8 \\
\hline \multicolumn{3}{|l|}{ Place of residence } \\
\hline Tubarão & 51 & 49.0 \\
\hline Nearby towns & 48 & 46.2 \\
\hline Other towns in Santa Catarina & 5 & 4.8 \\
\hline \multicolumn{3}{|l|}{ Residence area } \\
\hline Urban/peri-urban & 82 & 78.8 \\
\hline Rural & 13 & 12.5 \\
\hline No information & 9 & 8.7 \\
\hline \multicolumn{3}{|l|}{ Occupation } \\
\hline Studant & 2 & 1.9 \\
\hline Housewife & 54 & 51.9 \\
\hline Employed & 11 & 10.6 \\
\hline Self-employed & 6 & 5.8 \\
\hline Unemployed & 1 & 1.0 \\
\hline No information & 30 & 28.8 \\
\hline \multicolumn{3}{|l|}{ Pregnancy date } \\
\hline \multicolumn{3}{|l|}{ On ARV during pregnancy } \\
\hline Yes & 85 & 81.7 \\
\hline No & 14 & 13.5 \\
\hline No information & 5 & 4.8 \\
\hline \multicolumn{3}{|l|}{ On ARV during labor } \\
\hline Yes & 95 & 91.3 \\
\hline No & 5 & 4.8 \\
\hline No information & 4 & 3.9 \\
\hline \multicolumn{3}{|l|}{ Type of delivery } \\
\hline Vaginal & 17 & 16.3 \\
\hline Cesarean section & 83 & 79.8 \\
\hline No information & 4 & 3.9 \\
\hline
\end{tabular}

AMUREL=Associação dos Municípios da Região de Laguna. 
Epidemiological characteristics of newborns tested for HIV seroconversion through vertical transmission $(n=104)$ at the town's health care center. Southern Santa Catarina, 2005-2015.

\begin{tabular}{|c|c|c|}
\hline Newborn characteristics & N & $\%$ \\
\hline \multicolumn{3}{|l|}{ Gender } \\
\hline Male & 52 & 50.0 \\
\hline Female & 51 & 49.0 \\
\hline No information & 1 & 1.0 \\
\hline \multicolumn{3}{|l|}{ Skin color } \\
\hline White & 53 & 51.0 \\
\hline Non-white & 16 & 15.4 \\
\hline No information & 35 & 33.6 \\
\hline \multicolumn{3}{|c|}{ Prophylaxis with oral antiretroviral medications } \\
\hline Yes & 93 & 89.4 \\
\hline No & 5 & 4.8 \\
\hline No information & 6 & 5.8 \\
\hline \multicolumn{3}{|l|}{ Duration of ARV regimen (weeks) } \\
\hline$<3$ & 16 & 15.4 \\
\hline $3-5$ & 1 & 1.0 \\
\hline 6 & 51 & 49.0 \\
\hline No use & 2 & 1.9 \\
\hline No information & 34 & 32.7 \\
\hline \multicolumn{3}{|l|}{ Breastfeeding } \\
\hline Yes & 2 & 1.9 \\
\hline No & 98 & 94.2 \\
\hline No information & 4 & 3.9 \\
\hline \multicolumn{3}{|l|}{ Cross-feeding } \\
\hline Yes & 1 & 1.0 \\
\hline No & 99 & 95.1 \\
\hline No information & 4 & 3.9 \\
\hline \multicolumn{3}{|l|}{ Evolution } \\
\hline Infected & 3 & 2.9 \\
\hline Not infected & 77 & 74.0 \\
\hline Lost to follow-up & 14 & 13.5 \\
\hline Transferred out to other regions & 7 & 6.7 \\
\hline HIV-related deaths & 2 & 1.9 \\
\hline Death due to other causes & 1 & 1.0 \\
\hline
\end{tabular}

Table 3

Seroconversion description of five cases of HIV-infected newborns through vertical transmission, monitored at the town's health care center. Southern Santa Catarina, 2005-2015.

\begin{tabular}{|c|c|c|c|c|c|}
\hline Variables & Case 1 & Case 2 & Case 3 & Case 4 & Case 5 \\
\hline Maternal CD4 count (cels/mm³) $\dagger$ & 349 & 354 & 389 & 307 & 185 \\
\hline Maternal viral load (copies/mL) $†$ & 29,841 & 13,603 & 150 & 95,279 & 220,359 \\
\hline Antiretroviral therapy during pregnancy & No & No & No & Yes & No \\
\hline Antiretroviral therapy during labor & No & Yes & Yes & Yes & No \\
\hline Type of delivery & Vaginal & Cesarean & Cesarean & Cesarean & Vaginal \\
\hline Breastfeeding & Yes & No & No & Yes & No \\
\hline Oral prophylaxis (in weeks) & $2-5$ & $<3$ & $<3$ & $<3$ & $<3$ \\
\hline Outcome & Infected & Infected & Infected & Deceased & Deceased \\
\hline
\end{tabular}

tLast record available during pregnancy. 
Factors associated with HIV seroconversion in newborns through vertical transmission, monitored at the town's health care center. Southern Santa Catarina, 2005-2015.

\begin{tabular}{|c|c|c|c|c|c|c|}
\hline \multirow[t]{3}{*}{ Variables } & \multicolumn{4}{|c|}{ Seroconversion } & \multirow[t]{3}{*}{$p^{*}$} & \multirow{3}{*}{$\begin{array}{c}\text { Relative Risk } \\
\text { (Cl95\%) }\end{array}$} \\
\hline & \multicolumn{2}{|c|}{ Present } & \multicolumn{2}{|c|}{ Absent } & & \\
\hline & $\mathrm{n}$ & $\%$ & $\mathrm{n}$ & $\%$ & & \\
\hline ARV therapy during pregnancy $(n=99)$ & & & & & 0.008 & $18.2(2.0-163.0)$ \\
\hline No & 3 & 75.0 & 11 & 11.6 & & \\
\hline Yes & 1 & 25.0 & 84 & 88.4 & & \\
\hline ARV therapy during labor $(n=100)$ & & & & & 0.188 & $6.3(0.8-50.5)$ \\
\hline No & 1 & 25.0 & 4 & 4.2 & & \\
\hline Yes & 3 & 75,0 & 92 & 95.8 & & \\
\hline Type of delivery $(n=100)$ & & & & & 0.199 & $3.3(0.6-18.0)$ \\
\hline Vaginal & 2 & 40.0 & 15 & 15.8 & & \\
\hline Cesarean section & 3 & 60.0 & 80 & 84.2 & & \\
\hline Breastfeeding $(n=100)$ & & & & & 0.002 & $32.7(10.7-99.5)$ \\
\hline Yes & 2 & 40.0 & 0 & - & & \\
\hline No & 3 & 60.0 & 95 & 100.0 & & \\
\hline ARV therapy in infants $(n=80)$ & & & & & 0.235 & $4.7(0.6-34.3)$ \\
\hline No & 1 & 20.0 & 4 & 4.3 & & \\
\hline Yes & 4 & 80.0 & 89 & 95.7 & & \\
\hline
\end{tabular}

*Two-tailed Fisher's exact test.

\section{Table 5}

Case distribution and seroconversion rate in live births, monitored at the town's health care center. Southern Santa Catarina, 2005-2015.

\begin{tabular}{|c|c|c|c|c|c|}
\hline \multirow[t]{2}{*}{ Notification year } & \multirow[t]{2}{*}{ Notified cases ( $n$ ) } & \multirow[t]{2}{*}{ Life births (n) } & \multicolumn{3}{|c|}{ Seroconversion } \\
\hline & & & $\mathrm{n}$ & $\%$ & $\begin{array}{l}\text { Rate/1.000 } \\
\text { life births }\end{array}$ \\
\hline 2005 & 15 & 4,005 & 1 & 6.7 & 0.2 \\
\hline 2006 & 9 & 4,098 & - & - & - \\
\hline 2007 & 9 & 3,984 & - & - & - \\
\hline 2008 & 9 & 4,292 & 1 & 11.1 & 0.2 \\
\hline 2009 & 7 & 4,097 & - & - & - \\
\hline 2010 & 11 & 4,216 & - & - & - \\
\hline 2011 & 7 & 3,827 & - & - & - \\
\hline 2012 & 5 & 4,493 & 1 & 20.0 & 0.2 \\
\hline 2013 & 12 & 4,575 & 2 & 16.6 & 0.4 \\
\hline 2014 & 9 & 4,177 & - & - & - \\
\hline 2015 & 11 & 4,834 & - & - & - \\
\hline Total & 104 & 46,598 & 5 & 4.8 & 0.1 \\
\hline
\end{tabular}


to follow-up. ${ }^{11}$ These data corresponded to a seroconversion rate of 0.1 per 1,000 live births, the same rate found in the present study.

The use of zidovudine (AZT), defined by the Pediatric Clinical Trials Group ${ }^{10}$ protocol, reduced vertical transmission in almost $70 \%$ of cases. Currently, a triple antiretroviral medicine regimen is recommended, together with indicating the route of delivery, depending on the plasma viremia, for less fetal involvement. Furthermore, HIV-infected mothers should avoid breastfeeding, and AZT should be administered orally to the newborn until six weeks after birth. When these recommendations are followed, vertical transmission reaches rates no higher than $1 \%$ or $2 \% .12,13$ The use of AZT, even when administered at a late stage of pregnancy, or when administered only to the newborn after birth, reduces vertical HIV transmission, regardless of the viral load level.14 Findings from this study revealed that the non-use of ARV during gestation and breastfeeding were the factors statistically associated with seroconversion of HIV infection in the newborn. Late diagnosis, coupled with ignorance about HIV transmission routes, such as breastfeeding, may contribute to increase vertical transmission. Furthermore, a little more than half of the newborns used ARV until the recommended six-week period after birth, which revealed the mothers' failure to comply with the vertical transmission prophylaxis protocol. This behavior may be explained by the difficulty mothers of infected infants (data not shown) have in adhering to their own treatment regiments. Pregnant women who neglect their own recommended treatment tend to neglect a proper care of their babies, as already evidenced in other studies. $14-17$

A small number of pregnant women living with HIV did not use ARV during gestation and delivery. This unsatisfactory coverage revealed that the health surveillance system should have a better information system to identify pregnant women who lack prenatal care $7,15,16$ or are unaware of their serological status before delivery. Pregnant women who come late for antenatal care (after week 16 of gestation) are less likely to receive an effective prevention. When HIV infection is diagnosed during pregnancy, ART should be started immediately, and no later than week 14 of gestation to avoid prolonged exposure to a high viral load. ${ }^{18,19}$ In the cases of confirmed seroconversion, the majority had a high viral load and a low CD4 T-lymphocyte count, which revealed immunodepression among women, favoring mother-to-infant transmission. 14,16,19 It should be noted that the date of initiation of ARV in gestation is not included in the Brazilian information system for notifiable diseases (Sinan, Portuguese acronym). The Sinan form only indicates whether the pregnant woman is or is not using ARV, without informing the initiation date, which makes it difficult to assess this aspect in relation to the infected outcome.

Seropositive pregnant women with a viral load greater than or equal to 1,000 copies $/ \mathrm{mL}$, or unknown status after week 34 of gestation should undergo cesarean section, with infusion of AZT three hours before surgery until delivery. 6,7 If a woman arrives at the hospital in early labor, AZT should be started right away until delivery, avoiding umbilical cord blood and amniotic fluid collection, and the use of forceps, for example.6,10,20 In the present study, cesarean section was the predominant mode of delivery. However, there was no record of maternal viral load in the peripartum. In less than $20 \%$, vaginal delivery was chosen due to the evolution of labor. In vaginal delivery, episiotomy should be avoided, and labor should be monitored using an evolution chart (partograph), avoiding repeated vaginal touches. 6,7

In 2004, a study conducted at the Clinical Hospital of the Federal University of Minas Gerais assessed 85 seropositive pregnant women who attended the health care service. More than half of the pregnant women $(56.7 \%)$ received ARV as a therapeutic indication and $43.3 \%$ as a prophylaxis for vertical transmission. Vaginal delivery accounted for $27.6 \%$ of total deliveries, and no vertical transmission was observed.15 In 2007, a study conducted on 389 seropositive pregnant women in Belo Horizonte, Minas Gerais, revealed that $48.6 \%$ had started treatment between week 14 and week 27 of gestation, and seroconversion was $5.7 \%$, results that were similar to those of the present study. ${ }^{21}$

Global HIV 90-90-90 targets were set to end the AIDS epidemic by 2020 , which means that by 2020 , $90 \%$ of all people living with HIV will know their HIV status, $90 \%$ of all people with diagnosed HIV infection will receive antiretroviral therapy, and 90\% of all people receiving antiretroviral therapy will have viral suppression to end Aids epidemic by 2030.22 For that purpose, the disease evolution must be monitored concomitantly with the advancement of society to assess the need for rearrangement in HIV/Aids programs, adequacy of public policies, protocols of coping strategies, and hospital care routines. It is also necessary to evaluate program management, and roles and responsibilities of the different levels of government to address this issue. Although there are efficient protocols for the preven- 
tion of vertical HIV transmission, and availability of antiretroviral drugs to all pregnant women, indicators are still unfavorable. 5

Some limitations exist in the current study, beginning with the data being collected from secondary records, with several information gaps and follow-up losses that may have influenced the data analysis. The notification forms were not properly filled, with some blank answers, high rates of loss of follow-up or transfer out, when the case closes without a conclusion, and double notifications within the same state, revealing the fragility of data contained in the national bulletins.

There were some technical difficulties to collect such data, given that, in spite of the national notification system of exposure, the records were kept on physical files. At the end of the 18-month period, the case was notified according to the outcome, without correlation between maternal and newborn HIV exposure. Therefore, the infant could be notified more than once, according to the health service. Death and seroconversion data are only available through a direct online consultation with the Epidemiological Surveillance System in each

\section{References}

1. Joint United Nations Programme on HIV/AIDS. Global Report: UNAIDS report on the global AIDS epidemic 2016. Geneve: Word Heath Organization; 2018. [acesso em 30 mar 2018]. Disponível em: http://www.unaids.org/sites/ default/files/media_asset/global-AIDS-update2016_en.pdf.

2. Joint United Nations Programme on HIV/AIDS (UNAIDS). Aidsinfo. Graphs. Children (0-14) living with HIV. [acesso em 8 abr 2018] Disponível em: http://aidsinfo.unaids.org/..

3. Joint United Nations Programme on HIV/AIDS (UNAIDS). How AIDS changed everything. Mdg 6: 15 years, 15 lessons of hope from the AIDS response. [acesso em $1 \mathrm{abr}$ 2018] Disponível em: http://www.unaids.org/sites/default/ files/media_asset/MDG6Report_en.pdf.

4. Grangeiro A, Castanheira ER, Nemes MIB. A reemergência da epidemia de aids no Brasil: desafios e perspectivas para o seu enfrentamento. Interface (Botucatu). 2015; 19 (52): 5-6.

5. Brasil. Ministério da Saúde. Secretaria de Vigilância em Saúde. Departamento Nacional de DST, Aids e Hepatites Virais. Boletim Epidemiológico Aids/DST. Brasília, DF; 2015. [acesso em 3 jan 2018]. Disponível em: http://www.aids.gov.br/sites/default/files/anexos/publicacao/2015/58534/boletim_aids_11_2015_web_pdf_19105 .pdf.

6. Brasil. Ministério da Saúde. Protocolo para a prevenção de transmissão vertical de HIV e sífilis - Manual de Bolso do Ministério da Saúde. [acesso em 9 abr 2018] Disponível
Brazilian state. The Sinan does not provide data on seroconversion for regional, state, or national comparisons.

Our study concluded that HIV seroconversion among live births was $4.8 \%$ between 2005 and 2015 . Seroconversion was associated with no use of antiretroviral therapy during gestation and breastfeeding, showing flaws in prenatal care. Evidently, the WHO targets for ending vertical transmission have not yet been met. Therefore, it is important to provide prenatal care to all pregnant women, with an early diagnosis of HIV infection, to follow the prophylaxis protocol for vertical transmission.

Education programs focusing on pregnant women about mother-to-child HIV transmission may increase adherence to ARV and halt breastfeeding.

\section{Acknowledgments}

We would like to thank the Specialized Health Care Center and the Epidemiological Surveillance of the Municipality of Tubarão for allowing access to the data and facilitating the collection of information needed for this study. em: http://bvsms.saude.gov.br/bvs/publicacoes/protocolo _prevencao_transmissao_vertialhivsifilis_manualbolso.pdf.

7. Brasil. Ministério da Saúde. Secretaria de Vigilância em Saúde. Departamento de DST, Aids e Hepatites Virais. Protocolo clínico e diretrizes terapêuticas para manejo da infecção pelo HIV em crianças e adolescentes. Brasil; 2014. [acesso em 28 mar 2018]. Disponível em: http://www.aids.gov.br/sites/default/files/anexos/publicacao/2014/55939/08_05_2014_protocolo_pediatrico_pdf 36225.pdf.

8. IBGE (Instituto Brasileiro de Geografia e Estatística) População, CENSO 2010. [acesso em 10 mar 2018]. Disponível em: http://www.ibge.gov.br/home/estatistica/ populacao/censo2010/tabelas_pdf/total_populacao_santa_c atarina.pdf.

9. DATASUS (Departamento de Informática do SUS). Informações em Saúde. Estatísticas Vitais. Nascidos Vivos. [acesso em 10 abr 2018]. Disponível em: http://tabnet.datasus.gov.br/cgi/deftohtm.exe?sinasc/cnv/nv sc.def

10. Connor EM, Sperling SR, Gelber R, Kiselev P, Scott G, O'Sullivan MJ, et al. Reduction of maternal-infant transmission of human immunodeficiency virus type 1 with zidovudine treatment. For the Pediatric AIDS Trials Group Protocol 076 Study Group. N Engl J Med. 1994; 331 (18): 1173-80.

11. Diretoria de Vigilância Epidemiológica do Estado de Santa Catarina. Epiinfo/DIVE/SUV/SES-SC. [acesso em 9 abr 
2018].Disponível em: http://www.dive.sc.gov.br/index.php/ sistemas-de-informacao.

12. Sinunu MASE, Wadonda N, Kajowa E, Eliya M, Moyo K, Chimbwandira F, Strunin L,Kellerman SE. Evaluating the impact of prevention of mother-to-child transmission of HIV in Malawi through immunization clinic-based surveillance. PLoS One. 2014; 9 (6): e100741.

13. Ioannidis JP, Tatsioni A, Abrams EJ, Bulterys M, Coombs RW, Goedert JJ, et al. Maternal viral load and rate of disease progression among vertically HIV-1-infected children: an international meta-analysis.AIDS. 2004; 18 (1) 99-108.

14. Brasil. Ministério da Saúde Secretaria de Vigilância em Saúde Programa Nacional de DST e AIDS. Recomendações para Profilaxia da Transmissão Vertical do HIV e Terapia Antirretroviral em Gestantes. [acesso em 3 dez 2017]. Disponível em: http://www.infectologia.org.br/wpcontent/uploads/2014/01/Consenso-brasileiro-da-TARVem-gestantes-2006.pdf

15. Lima ACMACC, Costa CC, Teles LMR, Damasceno AKC, Oriá MOB. Avaliação epidemiológica da prevenção da transmissão vertical do HIV. Acta Paul Enferm. 2014; 27 (4): 311-8.

16. Romanelli RM, Kakehasi FM, Tavares MC, Melo VH, Goulart LH, Aguiar RA, Pinto JA.Perfil das gestantes infectadas pelo HIV atendidas em pré-natal de alto risco de referência de Belo Horizonte. Rev Bras Saúde Mater Infant. 2006; 6 (3): 329-34.

17. Freitas JG, Barroso LMM, Galvão MTG. Capacidade de mães para cuidar de crianças expostas ao HIV. Rev LatinoAmEnferm. 2013; 21 (4): 964-72.
18. Brasil. Ministério da Saúde. Secretaria de Políticas de Saúde. Coordenação Nacional de DST e AIDS. Vigilância do HIV no Brasil-novas diretrizes; 2002. [acesso em 25 mar 2018]. Disponível em: http://bvsms.saude.gov.br/bvs/publicacoes/162vig_hiv_005.pdf

19. Duarte G, Quintana SM, El Beitune P. Estratégias que reduzem a transmissão vertical do vírus da imunodeficiência humana tipo 1. Rev Bras Ginecol Obstet. 2005; 27 (12): 768-78.

20. Cooper ER, Charurat M, Mofenson L, Hanson IC, Pitt J, Diaz C, Hayani K, Handelsman E, Smeriglio V, Hoff R, Blattner W; Women and Infants' Transmission Study Group. Combination of antiretroviral strategies for the treatment of pregnant HIV-1 infected women and prevention of perinatal HIV-1 transmission. J Acquir Immune Defic Syndr. 2002; 29 (5): 484-94

21. Lana FCF, Lima AS. Avaliação da prevenção da transmissão vertical do HIV em Belo Horizonte, MG, Brasil. Rev Bras Enferm. 2010; 63 (4): 587-94.

22. UNAIDS. 90-90-90 An ambitious treatment target to help end the AIDS epidemic. [acesso em 20 jan 2018]. Disponível em: http://www.unaids.org/en/resources/documents/2014/90-90-90

Received on October 4, 2017

Final version presented on June 11, 2018

Approved on July 17, 2018 